\title{
Determination of tsunami run-up and golden time in the megathrust subduction zone of the sunda strait segment
}

\author{
Iko Sarikanti Ponangsera ${ }^{1 *}$, Anwar Kurniadi $^{1}$, Deffi Ayu Puspitosari ${ }^{1}$, and Dedy Hartono ${ }^{1}$ \\ ${ }^{1}$ Disaster Management Study Program, National Security Faculty, Republic of Indonesia Defense University, IPSC Sentul Area, \\ Bogor, West Java, Indonesia
}

\begin{abstract}
The Indonesian Disaster Data and Information Management Database state that the tsunami in the Megathrust Subduction Zone of the Sunda Strait Segment is a disaster threat with high impact and loss of life every time it occurs. Therefore, determining the run-up and golden time of the tsunami in the Megathrust Subduction Zone of the Sunda Strait Segment is necessary as part of the mitigation of seismic activity that has the potential for a tsunami. The design of this study is qualitative research with primary data to determine the run-up and golden time of the tsunami in the Megathrust Subduction Zone of the Sunda Strait Segment obtained from the Indonesia Tsunami Warning System (InaTEWS) at BMKG. The results of the study inform that seismic activity in the Megathrust Subduction Zone of the Sunda Strait Segment can cause a tsunami with a run-up of 5.99 meters and a golden time of 40 minutes 19 seconds in Banten and South Lampung, the run-up of 3.83 meters, and a golden time of 1 hour 1 minute 10 seconds in Pacitan, East Java, run up 3.28 meters and golden time 33 minutes 15 seconds in Pangandaran, West Java.
\end{abstract}

\section{Introduction}

One of the tasks of the state is to protect the entire nation and the homeland of Indonesia from various kinds of threats. Threats are every effort or activity that intends to threaten and endanger state sovereignty, territorial integrity, and the safety of all nations, both from within and outside the country $[1,2]$.

The characteristics of threats are divided into 2 , namely military threats and non-military threats [3-5]. The shift in the characteristics of military threats to nonmilitary ones, such as an increase in the number of incidents and impacts due to disasters, is one of the directions of Indonesia's attention in strengthening state protection for the human security of its citizens [4].

Indonesia's geography, which is located between 4 active tectonic plates of Eurasia, Indo-Australia, Pacific, and the Philippines [6,7] makes Indonesia has a high risk of earthquakes and tsunamis [8,9].

The movement of plates in various directions causes a subduction zone of the Sumatran plate to the Java segment $[10,11]$. The subduction zone due to plate movement is commonly known as Megathrust. Indonesia itself has 13 megathrusts, namely, Aceh-Andaman, Nias-Simelue, Batu, Mentawai Siberut, Mentawai-Pagai, Enggano, Sunda Strait, West Java-Central Java, East Java, Sumba, North Sulawesi, the Philippines, and Papua [12-14]. The 13 megathrusts can be seen in Fig. 1.

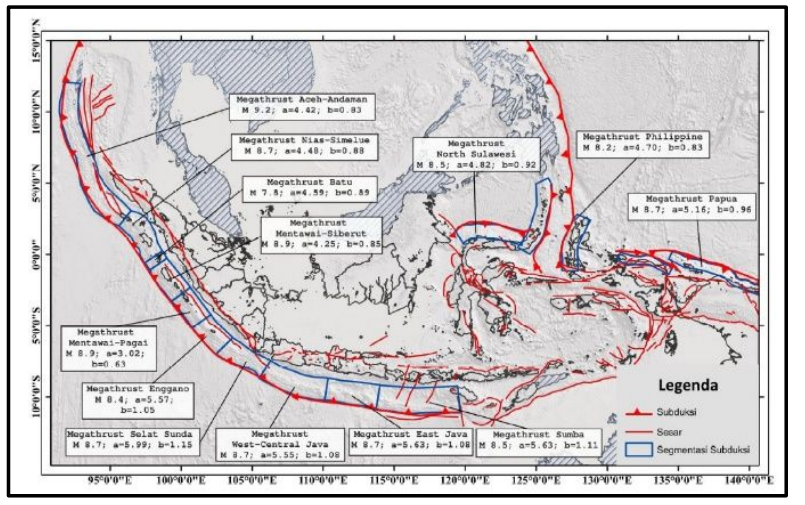

Fig. 1. Segmentation Map and Maximum Subduction Magnitude of Indonesia [14].

The 13 megathrusts in Indonesia have the potential for earthquakes with their epicenters around the subduction zone of the plate. Deformation and subduction movements of tectonic plates are the reason for the formation of active faults on the seabed and land. This is what causes the potential for tectonic earthquakes to often occur in Indonesia [15].

In addition, the movement of tectonic plates also causes the formation of active volcanoes throughout Indonesia, or commonly known as the Ring of Fire. Indonesia's geography is what makes it a high-risk index for volcanic eruptions, earthquakes, and tsunamis [14].

\footnotetext{
${ }^{*}$ Corresponding author: ikoponangsera@yahoo.co.id
} 
The historical distribution of earthquakes in Indonesia can be seen in Fig. 2.

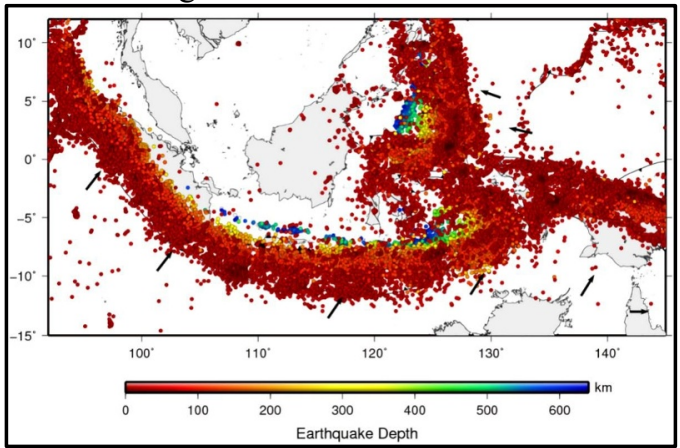

Fig. 2. Indonesia Earthquake Event Map [14].

Seismic activity in the Megathrust Subduction Zone of the Sunda Strait Segment is one of the meeting activities of the Indo-Australian and Eurasian plates which has the potential for a tsunami in the south of the islands of Sumatra and Java $[10,14,16,17]$, as shown in Fig. 3.

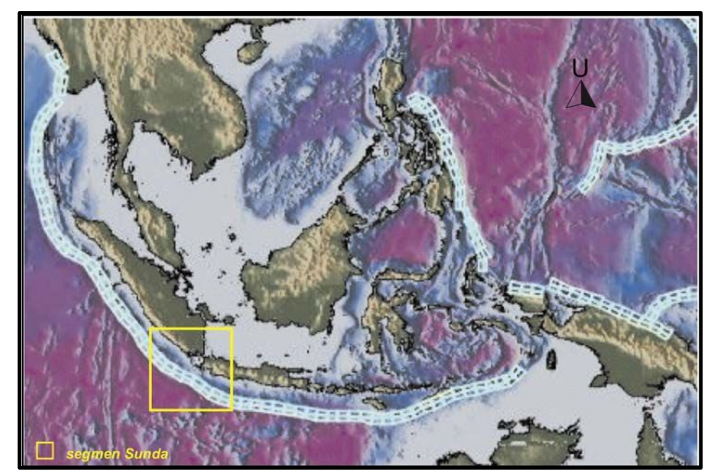

Fig. 3. Location of tsunami sources due to earthquakes associated with subduction zones (series of segments following the pattern of subduction zones) [18].

Fig. 3 explains that the Megathrust Subduction Zone of the Sunda Strait Segment is one of the tsunamigenic zones in Indonesia that can potentially cause a tsunami. Therefore, research to determine the run-up and golden time of the tsunami in the Megathrust Subduction Zone of the Sunda Strait Segment are necessary as part of disaster mitigation efforts to protect the Indonesian people from the threat of a potential tsunami disaster and as a form of national security.

\section{Study Method}

The design of this study is qualitative research with primary data to determine the run-up and golden time of the tsunami in the Megathrust Subduction Zone of the Sunda Strait Segment obtained from the Indonesia Tsunami Warning System (InaTEWS) at BMKG.

The guideline for modeling tsunami potential in this study uses the Tsunami Observation and Simulation Terminal software at BMKG. The time of occurrence of the earthquake (origin time) for tsunami modeling in the Megathrust Subduction Zone of the Sunda Strait Segment is 19:34:02 WIB with a strength of M 9.2. The modeling locations are at $8.23^{\circ} \mathrm{N}$ and $104.36^{\circ}$ East with an epicenter of $20 \mathrm{~km}$, as shown in Fig. 4.

\section{Result and Discussion}

The results of data processing get output in the form of an animation modeling the occurrence of a tsunami in the Megathrust Subduction Zone of the Sunda Strait Segment.

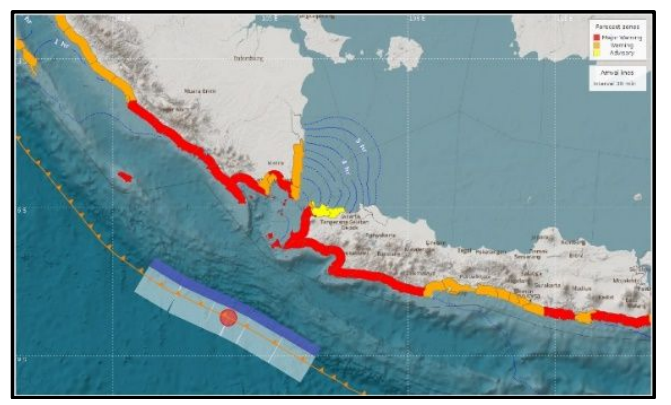

Fig. 4. Tsunami Modeling Parameters in the Megathrust Subduction Zone of the Sunda Strait Segment.

The tsunami modeling scenario in the Tsunami Observation and Simulation Terminal software uses the EasyWave2 model with parameters M 8.7 SR and epicenter $10 \mathrm{~km}$. This was chosen because the spread and propagation of tsunami waves can be seen within 6 hours with the location of the tsunami wave propagation spreading to various areas. The tsunami modeling wave propagation in the Megathrust Subduction Zone of the Sunda Strait Segment can be seen in Fig. 5.

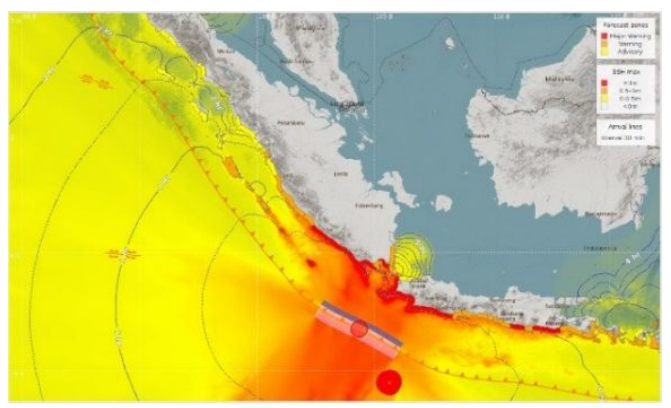

Fig. 5. Tsunami Modeling Wave Propagation in the Megathrust Subduction Zone of the Sunda Strait Segment.

Based on the modeling using the TOAST software, information on the status of tsunami early warnings in various areas with the potential for a tsunami to occur due to an earthquake is generated in the Megathrust Subduction Zone of the Sunda Strait Segment. The tsunami early warning status uses 3 levels, namely alert, alert, and alert. The alert level in this modeling is given if the estimated tsunami wave height reaches $>3$ meters, the alert warning level in this model is given if the estimated tsunami wave height reaches 0.5 meters to 3 meters, the alert warning level in this model is given if the predicted wave height is tsunami reaches $<0.5$ meters $[19,20]$. Information on potential tsunami areas can be seen in Table 1. 
Table 1. Potential areas affected by the tsunami.

\begin{tabular}{|c|c|c|c|}
\hline $\begin{array}{l}\text { Tsunami } \\
\text { Modeling } \\
\text { Time }\end{array}$ & $\begin{array}{l}\text { Golden } \\
\text { Time }\end{array}$ & $\begin{array}{l}\text { Tsunami } \\
\text { Early } \\
\text { Warning } \\
\text { Level }\end{array}$ & $\begin{array}{l}\text { Potential } \\
\text { Tsunami } \\
\text { Affected Areas }\end{array}$ \\
\hline $\begin{array}{l}19: 54: 45 \\
\text { WIB }\end{array}$ & $00: 05: 10$ & Awas & $\begin{array}{l}\text { Pandeglang, } \\
\text { Banten }\end{array}$ \\
\hline $\begin{array}{l}\text { 19:54:45 } \\
\text { WIB }\end{array}$ & 00:09:30 & Awas & Lebak, Banten \\
\hline $\begin{array}{l}\text { 19:54:45 } \\
\text { WIB }\end{array}$ & $00: 45: 49$ & Awas & Serang, Banten \\
\hline $\begin{array}{l}19: 54: 45 \\
\text { WIB }\end{array}$ & $00: 59: 55$ & Siaga & $\begin{array}{l}\text { Kota Cilegon, } \\
\text { Banten }\end{array}$ \\
\hline $\begin{array}{l}\text { 19:54:45 } \\
\text { WIB }\end{array}$ & $00: 28: 55$ & Awas & $\begin{array}{l}\text { Kep. Sebuku, } \\
\text { Lampung Selatan }\end{array}$ \\
\hline $\begin{array}{l}19: 54: 45 \\
\text { WIB }\end{array}$ & $00: 21: 04$ & Awas & $\begin{array}{l}\text { Kep. Krakatau, } \\
\text { Lampung Selatan }\end{array}$ \\
\hline $\begin{array}{l}19: 54: 45 \\
\text { WIB }\end{array}$ & $00: 20: 45$ & Awas & $\begin{array}{l}\text { Kep. Legundi, } \\
\text { Lampung Selatan }\end{array}$ \\
\hline $\begin{array}{l}\text { 19:54:45 } \\
\text { WIB }\end{array}$ & $00: 50: 15$ & Awas & $\begin{array}{l}\text { Kalianda, } \\
\text { Lampung Selatan }\end{array}$ \\
\hline $\begin{array}{l}19: 54: 45 \\
\text { WIB }\end{array}$ & $00: 50: 45$ & Siaga & $\begin{array}{l}\text { Bakauheni, } \\
\text { Lampung Selatan }\end{array}$ \\
\hline $\begin{array}{l}19: 54: 45 \\
\text { WIB }\end{array}$ & 01:08:00 & Siaga & $\begin{array}{l}\text { Panjang, Kota } \\
\text { Bandar Lampung }\end{array}$ \\
\hline $\begin{array}{l}19: 54: 45 \\
\text { WIB }\end{array}$ & $00: 17: 04$ & Awas & $\begin{array}{l}\text { Pulau Tabuan, } \\
\text { Tanggamus }\end{array}$ \\
\hline $\begin{array}{l}19: 54: 45 \\
\text { WIB }\end{array}$ & $01: 54: 45$ & Siaga & Lampung Timur \\
\hline $\begin{array}{l}19: 54: 45 \\
\text { WIB }\end{array}$ & 00:18:00 & Awas & $\begin{array}{l}\text { Pesisir Tengah, } \\
\text { Lampung Barat }\end{array}$ \\
\hline $\begin{array}{l}\text { 19:54:45 } \\
\text { WIB }\end{array}$ & $00: 16: 25$ & Awas & $\begin{array}{l}\text { Pesisir Selatan, } \\
\text { Lampung Barat }\end{array}$ \\
\hline $\begin{array}{l}\text { 19:54:45 } \\
\text { WIB }\end{array}$ & 00:08:30 & Awas & $\begin{array}{l}\text { Pelabuhan Ratu, } \\
\text { Sukabumi, Jawa } \\
\text { Barat }\end{array}$ \\
\hline $\begin{array}{l}19: 54: 45 \\
\text { WIB }\end{array}$ & $00: 13: 49$ & Awas & Garut, Jawa Barat \\
\hline $\begin{array}{l}19: 54: 45 \\
\text { WIB }\end{array}$ & 00:11:00 & Awas & $\begin{array}{l}\text { Sindangbarang, } \\
\text { Cianjur, Jawa } \\
\text { Barat }\end{array}$ \\
\hline $\begin{array}{l}19: 54: 45 \\
\text { WIB }\end{array}$ & $00: 19: 55$ & Awas & $\begin{array}{l}\text { Tasikmalaya, } \\
\text { Jawa Barat }\end{array}$ \\
\hline $\begin{array}{l}19: 54: 45 \\
\text { WIB }\end{array}$ & $00: 25: 04$ & Siaga & $\begin{array}{l}\text { Ciamis, Jawa } \\
\text { Barat }\end{array}$ \\
\hline $\begin{array}{l}\text { 19:54:45 } \\
\text { WIB }\end{array}$ & $00: 50: 40$ & Awas & $\begin{array}{l}\text { Wonogiri, Jawa } \\
\text { Tengah }\end{array}$ \\
\hline $\begin{array}{l}19: 54: 45 \\
\text { WIB }\end{array}$ & $00: 45: 40$ & Siaga & $\begin{array}{l}\text { Purworejo, Jawa } \\
\text { Tengah }\end{array}$ \\
\hline $\begin{array}{l}\text { 19:54:45 } \\
\text { WIB }\end{array}$ & $00: 42: 34$ & Siaga & $\begin{array}{l}\text { Kebumen, Jawa } \\
\text { Tengah }\end{array}$ \\
\hline $\begin{array}{l}19: 54: 45 \\
\text { WIB }\end{array}$ & $00: 40: 45$ & Siaga & $\begin{array}{l}\text { Cilacap, Jawa } \\
\text { Tengah }\end{array}$ \\
\hline $\begin{array}{l}\text { 19:54:45 } \\
\text { WIB }\end{array}$ & $01: 00: 45$ & Awas & $\begin{array}{l}\text { Malang, Jawa } \\
\text { Timur }\end{array}$ \\
\hline $\begin{array}{l}\text { 19:54:45 } \\
\text { WIB }\end{array}$ & $00: 58: 49$ & Awas & $\begin{array}{l}\text { Tulungagung, } \\
\text { Jawa Timur }\end{array}$ \\
\hline $\begin{array}{l}19: 54: 45 \\
\text { WIB }\end{array}$ & $00: 59: 49$ & Awas & $\begin{array}{l}\text { Blitar, Jawa } \\
\text { Timur }\end{array}$ \\
\hline $\begin{array}{l}\text { 19:54:45 } \\
\text { WIB }\end{array}$ & $00: 53: 10$ & Awas & $\begin{array}{l}\text { Pacitan, Jawa } \\
\text { Timur }\end{array}$ \\
\hline $\begin{array}{l}\text { 19:54:45 } \\
\text { WIB }\end{array}$ & $01: 04: 34$ & Siaga & $\begin{array}{l}\text { Pulau } \\
\text { Nusabarung, } \\
\text { Jawa Timur }\end{array}$ \\
\hline
\end{tabular}

Table 1 explains that earthquakes in the Megathrust Subduction Zone of the Sunda Strait Segment can have the potential for a tsunami with a tsunami early warning level in the alert category in parts of Banten Province, such as Pandeglang, Lebak, and Serang.

In Lampung Province, seismic activity in the Megathrust Subduction Zone of the Sunda Strait Segment has the potential for a tsunami with the alert category in Kec. Rajabasa, Kalianda, Tanggamus, to the Central Coast and the West Coast.

Seismic activity in the Megathrust Subduction Zone of the Sunda Strait Segment also has the potential for tsunamis in areas in southern Java, such as West Java, Central Java, and East Java.

The shortest tsunami arrival time difference is in the Pandeglang area, Banten with a golden time of 5 minutes 10 seconds, Lebak with a golden time of 9 minutes 30 seconds. The golden time is the time difference to evacuate or save oneself from the threat of a potential tsunami after an earthquake in the Megathrust Subduction Zone of the Sunda Strait Segment.

In addition, the TOAST software's tsunami modeling output in the Megathrust Subduction Zone of the Sunda Strait Segment also produces estimates of tsunami run-up and golden time, as can be seen in Table 2 .

Table 2. Estimated Run up and Golden Time Tsunami.

\begin{tabular}{|l|l|l|l|}
\hline $\begin{array}{l}\text { Tsunami } \\
\text { Modeling } \\
\text { Time }\end{array}$ & $\begin{array}{l}\text { Run up } \\
\text { tsunami }\end{array}$ & $\begin{array}{l}\text { Golden } \\
\text { Time }\end{array}$ & $\begin{array}{l}\text { Potential } \\
\text { Tsunami } \\
\text { Affected Areas }\end{array}$ \\
\hline $\begin{array}{l}\text { 12:54:45 } \\
\text { WIB }\end{array}$ & $\begin{array}{l}5,99 \\
\text { meter }\end{array}$ & $00: 40: 19$ & $\begin{array}{l}\text { Pandeglang, } \\
\text { Banten }\end{array}$ \\
\hline $\begin{array}{l}\text { 12:54:45 } \\
\text { WIB }\end{array}$ & $\begin{array}{l}5,99 \\
\text { meter }\end{array}$ & $00: 40: 19$ & $\begin{array}{l}\text { Kec. Rajabasa, } \\
\text { Lampung } \\
\text { Selatan }\end{array}$ \\
\hline $\begin{array}{l}\text { 12:54:45 } \\
\text { WIB }\end{array}$ & $\begin{array}{l}3,83 \\
\text { meter }\end{array}$ & $00: 56: 49$ & $\begin{array}{l}\text { Pacitan, Jawa } \\
\text { Timur }\end{array}$ \\
\hline $\begin{array}{l}\text { 12:54:45 } \\
\text { WIB }\end{array}$ & $\begin{array}{l}3,71 \\
\text { meter }\end{array}$ & $01: 01: 10$ & $\begin{array}{l}\text { Tulung Agung, } \\
\text { Jawa Timur }\end{array}$ \\
\hline $\begin{array}{l}12: 54: 45 \\
\text { WIB }\end{array}$ & $\begin{array}{l}3,28 \\
\text { meter }\end{array}$ & $00: 33: 15$ & $\begin{array}{l}\text { Pangandaran, } \\
\text { Jawa Barat }\end{array}$ \\
\hline $\begin{array}{l}\text { 12:54:45 } \\
\text { WIB }\end{array}$ & $\begin{array}{l}3,01 \\
\text { meter }\end{array}$ & $00: 39: 45$ & $\begin{array}{l}\text { Cilacap, Jawa } \\
\text { Tengah }\end{array}$ \\
\hline
\end{tabular}

Based on Table 2, tsunami modeling in the Megathrust Subduction Zone of the Sunda Strait Segment resulted in a tsunami run-up of 5.99 meters and a golden time of 40 minutes 19 seconds in Banten and South Lampung, a runup of 3.83 meters, and a golden time of 1 hour 1 minute 10 seconds. in Pacitan, East Java, the run-up was 3.28 meters and a golden time of 33 minutes 15 seconds in Pangandaran, West Java, and a run-up of 3.01 meters and a golden time of 39 minutes 45 seconds in Cilacap, Central Java.

\section{Conclusion}

The results of the study prove that seismic activity in the Megathrust Subduction Zone of the Sunda Strait Segment can have the potential for a tsunami with an alert status in the provinces of Banten, Lampung, West Java, Tangah Java, and East Java. 
The golden time or the difference in time for evacuation and saving from the threat of a potential tsunami after an earthquake in the Megathrust Subduction Zone of the Sunda Strait Segment varies from region to region. The fastest golden time is 5 minutes 10 seconds in Pandeglang, Banten.

The results of this study can be used as the basis for disaster mitigation policies due to seismic activity in the Megathrust Subduction Zone of the Sunda Strait Segment.

\section{References}

1. B. Lesmana, Y. Rusfiana, R. Gunawan, Peperangan Asimetrik 4, (2018).

2. L. Suryatni, J. Ilm. Huk. Dirgant. 10, (2020).

3. I. S. Ponangsera, R. K. Apriyadi, D. Hartono, and W. Wilopo, PENDIPA J. Sci. Educ. 5, 277 (2021)

4. S. Yulianto, R. K. Apriyadi, A. Aprilyanto, T. Winugroho, I. S. Ponangsera, and W. Wilopo, PENDIPA J. Sci. Educ. 5, 180 (2021)

5. J. Fitriyani, R. K. Apriyadi, T. Winugroho, D. Hartono, I. D. K. K. Widana, and W. Wilopo, PENDIPA J. Sci. Educ. 5, 322 (2021)

6. R. K. Apriyadi and R. Amelia, PENDIPA J. Sci. Educ. 5, 56 (2020)

7. A. Aprilyanto, R. K. Apriyadi, T. Winugroho, I. D. K. K. Widana, and W. Wilopo, PENDIPA J. Sci. Educ. 5, 284 (2021)

8. M. Yusfania, I. M. Anjasmara, A. L. Hadi, and B. Pramudya, in AIP Conf. Proc. (AIP Publishing LLC, 2017), p. 40008

9. Z. Zakaria and S. Sidarto, J. Geol. Dan Sumberd. Miner. 16, 115 (2015)
10. Y. Fauzi, W. Kongko, and K. S. Brotopuspito, in IOP Conf. Ser. Earth Environ. Sci. (IOP Publishing, 2020), p. 12051

11. R. McCaffrey, Annu. Rev. Earth Planet. Sci. 37, 345 (2009)

12. S. Widiyantoro, E. Gunawan, A. Muhari, N. Rawlinson, J. Mori, N. R. Hanifa, S. Susilo, P. Supendi, H. A. Shiddiqi, and A. D. Nugraha, Sci. Rep. 10, 1 (2020)

13. A. Muhammad, K. Goda, N. A. Alexander, W. Kongko, and A. Muhari, Nat. Hazards Earth Syst. Sci. 17, 2245 (2017)

14. Tim-PSGN, Buku Peta Sumber Dan Bahaya Gempa Indonesia Tahun 2017 (Pusat Litbang Perumahan dan Permukiman Kementerian PUPR, Bandung, 2017)

15. BNPB, Indeks Risiko Bencana Indonesia Tahun 2020 (Badan Nasional Penanggulangan Bencana, Jakarta, 2021)

16. W. Widiyanto and S.-C. Hsiao, in IOP Conf. Ser. Mater. Sci. Eng. (IOP Publishing, 2020), p. 12034

17. W. Setyonegoro, S. Rohadi, B. Sunardi, Y. H. Perdana, T. Kurniawan, and U. Haryoko, in 43rd Annu. Sci. Meet. Himpun. Ahli Geofis. Indones. Semarang (2018)

18. Y. Yudhicara, K. Budiono, Indones. J. Geosci. 3, 241 (2008)

19. W. Kurniawan, E. Bangun, B. Prakoso, PENDIPA J. Sci. Educ. 5, 204 (2021)

20. R. K. Apriyadi, W. Kurniawan, S. Yulianto, S. Syamsunasir, I. D. K. K. Widana, A. Subiyanto, F. Bahar, D. C. Kuncoro, PENDIPA J. Sci. Educ. 6, 1 (2022) 